\title{
The Controversy over Accountants' WorkPAPERS- ARE THEY Protected from Disclosure to The Internal Revenue SERvice?
}

Ian 7. Redpath, Thomas 7. Vogel, and Eric M. Repdath

Ian J. Redpath is Professor of Accounting and Thomas J. Vogel is Associate Professor of Accounting at The Wehle School of Business, Canisius College.

\begin{abstract}
The protection of accountants' workpapers from disclosure has been a matter of controversy for many years. This is especially important with tax accrual workpapers and the expansion of FIN 48. The Internal Revenue Service has exacerbated the issue with the adoption of Schedule UTP requiring some corporations to disclose information on their uncertain tax positions. Work product protection has been available for workpapers prepared in "anticipation of litigation." Multiple problems arise when the workpapers are prepared for the corporation by independent accounting firms. Two cases in the federal courts have addressed this issue with dramatically different outcomes - Textron in 2009 and Deloitte in 2010. In 2010 the Service implemented the Schedule UTP. This paper examines the current state of work
\end{abstract}


product protection for workpapers in light of FIN 48, Schedule UTP requirements, Textron and Deloitte.

\section{INTRODUCTION}

The early 2000's brought about a series of financial and accounting scandals such as Enron, WorldCom and Adelphia. The result was a perceived loss of public confidence in the financial statements issued by public companies. The response came from State CPA Societies, regulatory agencies and Congress. Among the important responses were SarbanesOxley Act of 2002 (SOX), Financial Accounting Standards Board, Interpretation No. 48, Accounting for Uncertainty in Income Taxes (FIN 48) and the Internal Revenue Service's Schedule UTP.

SOX places certification and attestation requirements on corporations. Fin 48 mandates corporations to identify, quantify, and disclose all uncertain tax positions. These disclosures function to divulge the difference between the positions taken on a corporation's tax return and the potential that one or more positions could generate a tax liability in the future. The entity must report the potential aggregate impact on the financial statements of any tax benefit(s) claimed that may not be sustained if audited by the government. Fin 48 adopts a "more-likely-than-not standard" of review. This puts an added emphasis on the tax-accrual workpapers in determining the basis for the corporation's position regarding the sustainability of the tax position. These workpapers will usually require the assistance of legal counsel.

What constitutes workpapers can vary from situation to situation and the issues involved. The court in United States, et al v El Paso (1982), stated: "This appeal is centrally concerned with documents known to the accounting profession under various names -- the noncurrent tax account, the tax accrual work papers, and the tax pool analysis. Because the nomenclature is not standardized, the IRS chose to request El Paso's version of these documents under a loose descriptive label -- documents 
analyzing potential tax liabilities or tax problems. No matter what alias is used, however, the documents are of similar nature. It is useful to explain what these documents are before proceeding to determine whether the IRS may have access to them.” (U.S. v El Paso, 1982, p. 533) For this paper the term workpapers includes all of the above and is used in its generic context. Accountants prepare workpapers for many purposes that are not related to the determination of tax including regulatory purposes (i.e. SEC, SOX, FIN48 and Risk Management). Obtaining the workpapers can clearly be advantageous to the Internal Revenue Service in auditing a corporation and thus the Service has for years sought to obtain tax accrual work using its summons power.

In 2010, following up on the FIN 48, the Service adopted Schedule UTP -Uncertain Tax Position. The Service restated its policy of restraint regarding requests for documents provided to work-papers (Announcement 2010-76, 2010). Schedule UTP requires corporations to provide a concise description of each uncertain tax position for which the corporation or a related entity has recorded a reserve in its financial statements, or for which no reserve has been recorded because of an expectation of litigation. The Form does not include an assessment of the hazards of a tax position or an analysis of the support for or against the tax position. Additionally, the Service previously indicated a policy of restraint in requesting workpapers (Announcement 2002-63, 2002). unless the corporation was engaged in certain listed transactions or transactions of interest, which are determined to involve tax avoidance, e.g., an abusive tax shelter.( Treasury Regulation §301.6111-3, 2013).

While the Service's policy of restraint is of some benefit in the protection of work-papers, the basic protection is the "work product" privilege. Under this protection, workpapers may be protected from disclosure to the government if they are prepared in anticipation of litigation. 


\section{IRS Summons Power}

IRC § 7602 provides, in relevant part: “(a) AUTHORITY TO SUMMON, ETC. -For the purpose of ascertaining the correctness of any return, ... determining the liability of any person for any internal revenue tax ..., or collecting any such liability, the Secretary is authorized -- (1) To examine any books, papers, records, or other data which may be relevant or material to such inquiry."

In United States v. Arthur Young \& Co., the Supreme Court affirmed IRS's right to obtain auditor's tax accrual work papers and noted that the role of an accountant is very different from the role of an attorney. The accountant is a "public watchdog" and "owes ultimate allegiance to the corporation's creditors and stockholder, as well as to the investing public." (United States v. Arthur Young \& Co. 1984, p. 818) The court reasoned that IRC $\$ 7602$ gives the IRS a "broad summons authority" reflecting a "congressional policy choice in favor of disclosure of all information relevant to a legitimate IRS inquiry." (U. S. v. Arthur Young \& Co. 1984, p. 816) The IRS response was the adoption of the "policy of restraint" providing that the Service will only seek tax accrual workpapers in "unusual circumstances" (Announcement 2002-63, 2002-2 C.B. 72 , Internal Revenue Manual Sec. 4.10.20, 2010). The Service retains the policy of restraint even with the adoption of reporting in Schedule UTP. (Announcement 2010-76, 2010)

If a taxpayer does not comply with a summons, the IRS may seek an order from a Federal Court to enforce the summons. (IRC§7604) To be successful, the Service must show: "that the investigation will be conducted pursuant to a legitimate purpose, that the inquiry may be relevant to the purpose, that the information sought is not already within the Commissioner's possession, and that the administrative steps required by the Code have been followed, in particular, that the "Secretary or his delegate," after investigation, has determined the further examination to be necessary and has notified the taxpayer in writing to that effect." (United States v. Powell, 1964, p. 57-58) 
The legitimacy of the purpose for the disclosure is a facts and circumstances test. "Ascertaining the correctness of any return" and "determining the liability of any person for any internal revenue tax" as provided in IRC\$7602(a) are obviously legitimate purposes for issuing summons. However, it is not a legitimate purpose "to harass the taxpayer or to put pressure on him to settle a collateral dispute, or for any other purpose reflecting on the good faith of the particular investigation." (U.S. v. Powell, 1984 p. 58.) Even if the Service meets the Powell requirements, the court may reject enforcement of the summons if there is a privilege protecting the documents. The Court in Upjohn Co. v. United States (1981), recognized the attorney-client and work product privileges in tax summons cases. The burden is on the taxpayer to establish the privilege and that it has not been waived.

The attorney-client privilege protects confidential communications between attorneys and their clients with respect to legal advice. The purpose is to allow full and frank discussions between the client and attorney so that the attorney may provide sound legal advice. (Upjohn Co. v. United States, 1981 and Hunt v. Blackburn 1888). Legal advice, analysis and opinion are generally protected, even if related to the preparation of a return; however, the mere preparation of a tax return is not usually considered legal work and thus not generally protected. The attorney-client privilege is not absolute and may be the subject of a waiver.

\section{Tax Practitioner-Client Privilege}

Congress created a partial privilege for accountants. IRC $§ 7525$ was adopted in response to the court's holding in United States $v$ Arthur Young (1984).

IRC $§ 7525$ provides, in relevant part,

“(a) ... (1) GENERAL RULE. --With respect to tax advice, the same common law protections of confidentiality which apply to 
a communication between a taxpayer and an attorney shall also apply to a communication between a taxpayer and any federally authorized tax practitioner to the extent the communication would be considered a privileged communication if it were between a taxpayer and an attorney.

(2)LIMITATIONS. --Paragraph (1) may only be asserted in -- (A) any noncriminal tax matter before the Internal Revenue Service ...

(3)DEFINITIONS. --For purposes of this subsection --

(A)FEDERALLY AUTHORIZED TAX PRACTITIONER. --The term "federally authorized tax practitioner" means any individual who is authorized under Federal law to practice before the Internal Revenue Service if such practice is subject to Federal regulation under section 330 of title 31, United States Code.

(B)TAX ADVICE. --The term "tax advice" means advice given by an individual with respect to a matter which is within the scope of the individual's authority to practice described in subparagraph (A)."

IRC§7525(b) provides that the privilege does not apply to written communications between a federally authorized tax practitioner and the corporation "in connection with the promotion of the direct or indirect participation of such corporation in any tax shelter, as defined in IRC§6662(d)(2)(C)(iii)." The privilege does not extend to documents or communications related to the mere preparation of a tax return.

The privilege may also be the subject of a waiver similar to the attorney-client privilege. Disclosure to a third party, such as an independent auditor, will waive the tax practitioner privilege. A major exception to the privilege is that it does not apply to criminal actions. 


\section{Work Product Privilege}

The work-product privilege was first recognized by the Supreme Court in Hickman v. Taylor (1947). In that case, the plaintiff sought materials "secured by an adverse party's counsel in the course of preparation for possible litigation after a claim has arisen."(Hickman v. Taylor, 1947, p. 512) The Court held that, "written materials obtained or prepared by an adversary's counsel with an eye toward litigation," was protected from disclosure. The Court explained that "proper preparation of a client's case demands that he assemble information ... prepare his legal theories and plan his strategy without undue and needless interference." (Hickman v. Taylor, 1947, p. 512.) As Justice Jackson wrote in his concurring opinion, "[d]iscovery is hardly intended to enable a learned profession to perform its functions either without wits or with wits borrowed from the adversary." (Hickman v. Taylor, 1947, p. 516)

The Second Circuit Court, in United States v. Adlman (1998), stated the purpose of the privilege is "to preserve a zone of privacy in which a lawyer can prepare and develop legal theories and strategy 'with an eye toward litigation' free from unnecessary intrusion by his adversaries" (United States v. Adlman, 1998, p. 500 see also U.S. v. Frederick, 1999).

In 1970, the work product privilege was codified in Federal Rule of Civil Procedure §26(b)(3) which provides:

(3) Trial Preparation: Materials:

(A) Documents and Tangible Things: Ordinarily, a party may not discover documents and tangible things that are prepared in anticipation of litigation or for trial by or for another party or its representative (including the other party's attorney, consultant, surety, indemnitor, insurer, or agent). But, subject to Rule 26(b)(4), those materials may be discovered if:

(i)they are otherwise discoverable under Rule 26(b)(1); and 
(ii)the party shows that it has substantial need for the materials to prepare its case and cannot, without undue hardship, obtain their substantial equivalent by other means.

(B) Protection Against Disclosure: If the court orders discovery of those materials, it must protect against disclosure of the mental impressions, conclusions, opinions, or legal theories of a party's attorney or other representative concerning the litigation.

The work product privilege can be overcome by a showing of a substantial need for the materials which cannot be obtained without undue hardship. (FRCP§ 26(b)(3)(A)(ii)) However, this does not apply opinion work product which contains the "mental impressions, conclusions, opinions, or legal theories of an attorney or other representative of a party concerning the litigation", which are generally not discoverable. (FRCP $\S 26(\mathrm{~b})(3)(\mathrm{B}))$.

The work product privilege applies to an IRS summons. The Supreme Court observed: "[T]he obligation imposed by a tax summons remains 'subject to the traditional privileges and limitations.' . . . Nothing in the language of the IRS summons provisions or their legislative history suggests intent on the part of Congress to preclude application of the work product doctrine" (Upjohn v. U. S., 1981, p. 398-99).

Clearly the main inquiry must be whether the documents were prepared "in anticipation of litigation" and therefore subject to the privilege (FRCP§ 26(b)(3)(A)). There has been an absence of guidance from the Supreme Court since its decision in Hickman (1947). The Circuit Courts have established three different standards interpreting this term. These standards are, unfortunately, not consistent. Eight circuits have embraced a "because of" standard, protecting from disclosure documents prepared "because of" the prospect of litigation (U. S. v. Adlman, 1998, p. 1202-03). For this test, a document is privileged if, "in light of the nature of the document and the factual situation in the particular case, the docu- 
ment can be fairly said to have been prepared or obtained because of the prospect of litigation."(U.S. v. Adlman, 1998, p. 1202.)

The Fifth Circuit developed the "primary motivating purpose" test, which focuses on the primary purpose for which the document was prepared. To be protected, the primary motivating purpose in preparing the documents must be to assist in litigation (United States v. Davis, 1981).

The third test was established by the First Circuit in United States v. Textron (2009) this case conjured up its own idiosyncratic standard using a twist to the "because of" test providing protection for documents prepared for use in possible litigation.

There are clearly documents that are prepared for dual purposes, for example, to properly determine the reserve for potential tax liabilities and for possible use if audited by the Service. Is it litigation only if the matter goes to court? What is litigation? Generally litigation contemplates a proceeding that is "adversarial", there is right to cross-examine witnesses and the right to dispute evidence and legal arguments before a neutral arbiter. Clearly, this would include hearings before IRS Appeals and further resort to the courts. In United States v. Adlman (1998) the court stated: "It is universally agreed that a document whose purpose is to assist in preparation for litigation is within the scope of the Rule and thus eligible to receive protection if the other conditions of protection prescribed by the Rule are met. The issue is less clear, however, as to documents which, although prepared because of expected litigation, are intended to inform a business decision influenced by the prospects of the litigation [commonly referred to as dual purpose documents]. The formulation applied by some courts in determining whether documents are protected by work product privilege is whether they are prepared primarily or exclusively to assist in litigation -- a formulation that would potentially exclude documents containing analysis of expected litigation, if their primary, ultimate, or exclusive purpose is to assist in making the business decision. Others ask whether the documents were prepared 'because of existing or expected litigation -- a formulation that would 
include such documents, despite the fact that their purpose is not to 'assist in' litigation." (U. S. v. Adlman, 1998, p. 1197-1198). Accordingly, a document is privileged if, "in light of the nature of the document and the factual situation in the particular case, the document can be fairly said to have been prepared or obtained because of the prospect of litigation." ( $U$. S. v. Adlman, 1998, p. 1202).

The Adleman (1998) court applied the "because of" test to a situation where a document was procured to assist the parties in deciding whether to complete a proposed merger. The court ruled that "a document created because of anticipated litigation, which tends to reveal mental impressions, conclusions, opinions or theories concerning the litigation, does not lose work product protection merely because it is intended to assist in the making of a business decision influenced by the likely outcome of the anticipated litigation. Where a document was created, because of anticipated litigation, and would not have been prepared in substantially similar form but for the prospect of that litigation, it falls within Rule 26(b)(3)." (U. S. v. Adlman, 1998, p. 1195) However, the same may not be said of the other two tests.

\section{TEXTRON}

During the years in question, the IRS had audit staff permanently based at Textron. Textron's tax returns exceeded 4000 pages. In 2003, the IRS commenced an audit of Textron's corporate income tax liability for the years 1998-2001. During the audit, the Service became aware that Textron Financial Corporation (TFC), one of Textron's subsidiaries, had engaged in nine "listed" transactions. On its financial statements, the tax reserve amounts were aggregated and the total reported as "other liabilities". The Service issued more than 500 "information document requests" (IDRs) in connection with the examination. In regards to the 2001 return, the company refused to comply with the summons seeking its Workpapers based on the work product privilege. The IRS filed a peti- 
tion with the district court to enforce the summons for "Tax Accrual Work-papers" including:

"[A]ll accrual and other financial workpapers or documents created or assembled by the Taxpayer, an accountant for the Taxpayer, or the Taxpayer's independent auditor relating to any tax reserve for current, deferred, and potential or contingent tax liabilities, however classified or reported on audited financial statements, and to any footnotes disclosing reserves or contingent liabilities on audited financial statements. They include, but are not limited to, any and all analyses, computations, opinions, notes, summaries, discussions, and other documents relating to such reserves and any footnotes...."( U.S. v. Textron, 2009, p. 142).

The workpapers consisted of:

"1. A spreadsheet that contains:

(a)lists of items on Textron's tax returns, which, in the opinion of Textron's [and TFC's] counsel, involve issues on which the tax laws are unclear, and, therefore, may be challenged by the IRS [including the estimated dollar amounts];

(b)estimates by Textron's counsel expressing, in percentage terms, their judgments regarding Textron's chances of prevailing in any litigation over those issues (the "hazards of litigation percentages"); and

(c)the dollar amounts reserved to reflect the possibility that Textron might not prevail in such litigation (the "tax reserve amounts") [calculated by multiplying the amount estimated in (a) by the estimated percentage of likelihood of the IRS prevailing in (b)].

2. Backup workpapers consisting of the previous year's spreadsheet and earlier drafts of the spreadsheet together with notes and memoranda written by Textron's in-house tax attorneys reflecting their opinions as to which items should be included 
on the spreadsheet and the hazard of litigation percentage that should apply to each item" (U. S. v. Textron, 2009, p. 142-143).

The tax accrual workpapers contained the company's theories, opinions, arguments, and speculations about its contingent tax liabilities, i.e., the thought processes underlying the positions reported on the tax return. The opinions and conclusions of Textron's counsel and tax advisers, as embodied in the tax accrual work-papers, would provide the IRS a roadmap of the legal positions/arguments of Textron on its uncertain tax positions, providing an item-by-item analysis of the corporation's potential exposure to additional liability, including its negotiation and litigation strategy. These are the very "mental impressions" that the Court in Hickman sought to protect (U. S. v. Arthur Young and Co., 1984, p. 813). The determination of any tax owed by Textron must be based on factual information, available from the tax return or through formal requests for information, but not on opinions and thought processes of Textron's attorneys.

Textron provided its tax accrual workpapers to its auditors, Ernst \& Young and Co. to comply with the requirements under Federal Securities law that publicly traded corporations have their financial statements certified by an independent auditor. Of course, Ernst \& Young needed to review those workpapers to determine the "the adequacy and reasonableness of the corporation's reserve account for contingent liabilities". (U. S. v. Arthur Young and Co., 1984, p. 812.) Textron insisted that the information be kept confidential. This was also an ethical requirement under Section 301 of the AICPA Code of Professional Conduct.

The Service argued that the workpapers were not covered by the work product privilege because they were not prepared in "anticipation of litigation”. They also argued that Textron waived its privilege by disclosing the workpapers to their external auditors.

The District Court ruled that the workpapers were privileged as dual purpose documents and that the Service failed to satisfy the "substantial 
need" requirement under FRCP.§26(b)(3) to overcome the privilege. The court stated:

"[H]ere, the IRS has failed to carry the burden of demonstrating a substantial need for ordinary work product, let alone the heightened burden applicable to Textron's tax accrual work-papers, which constitute opinion work product. While the opinions and conclusions of Textron's counsel and tax advisers might provide the IRS with insight into Textron's negotiating position and/or litigation strategy, they have little bearing on the determination of Textron's tax liability.... The determination of any tax owed by Textron must be based on factual information, none of which is contained in the workpapers and all of which is readily available to the IRS through the issuance of IDRs and by other means. The opinions of Textron's counsel, either favorable or unfavorable, would have little to do with that determination, and forced disclosure of those opinions would put Textron at an unfair disadvantage in any dispute that might arise with the IRS, just as requiring the IRS to disclose the opinions of its counsel regarding areas of uncertainty in the law or the likely outcome of any litigation with Textron would place the IRS at an unfair disadvantage." (U. S. v. Textron, 2009, p.154-155).

The court also held that the disclosure to the outside auditors did not waive the privilege. Textron had an expectation of privacy in disclosing the documents to Ernst \& Young based both on its agreement and the AICPA Code of Professional Conduct. Thus disclosure did not increase the Services ability to obtain the information. (U. S. v. Textron, 2009, p.153).

The government appealed the decision of the District Court and the Court of Appeals for the First Circuit affirmed the decision of the lower court (this is often referred to as Textron II, 2009 ). The government requested reconsideration and in a 3-2 en banc decision the First Circuit reversed the lower court and appellate panel holding the workpapers were not protected from disclosure, however they agreed that disclosure to the accountants was not a waiver, While purporting to apply the 
"because of" test, the majority actually devised a third test; "prepared for use in litigation" test. The majority reasoned that the workpapers were required by the Securities laws and audit requirements; thus, they were not prepared for use in litigation. The majority did not look at the content of the documents to determine if it contained opinion information but focused exclusively on the reason for which they were prepared. The majority ignored the testimony of Textron's vice president of taxes that they would have prepared the workpapers regardless of GAAP and that another purpose of the workpapers was to guide them in making litigation and settlement decisions concerning the items in the tax reserve. The court held that the privilege's central aim is to protect the litigation process not shield documents prepared by a lawyer in the ordinary course of business. (U. S. v. Textron, Inc., 2009).

Underlying the opinion was a concern that the Service was disadvantaged in the war against large corporate tax evaders. The court balanced the policy concerns regarding the need for the IRS to defeat abusive tax shelters in favor of the government. It came close to establishing a rebuttable presumption in favor of disclosure. The majority found that the work-product protection provided "practical problems ... in discovering under reporting of corporate taxes". The Court found this problem to be "endemic" (U. S. v. Textron, Inc., 2009, p. 31) (McCarthy and Ryan, 2100, p. 154).

The scathing dissent noted that the court was not applying the "because of test" but establishing its own test. Further, the majority misrepresents and ignores the findings of the district court. All while purporting to do just the opposite of what it actually does." (U.S. v. Textron, Inc., 2009, p. 32). It reasoned that the majority opinion would have a chilling effect on lawyers writing down their thoughts. The workpapers "contain counsel's ultimate impression of the value of the case" thus they "contain exactly the sort of mental impressions about the case that Hickman sought to protect." (U. S. v. Textron, Inc., 2009, p. 36.) 
The decision in Textron (2009) provides the government with expansive power to require the disclosure of workpapers. The Court's failure to recognize that documents can serve more than one purpose and its failure to put any weight on the contents of the document could have the effect of severely limiting what is actually reduced to writing when workpapers are created. This case was appealed to the United States Supreme Court, however the Supreme Court refused to grant certiorari (U. S. v. Textron, Inc., 2010). The failure to grant certiorari does not mean the Justices agreed with the appeal court, however it does mean that the decision stands as precedent in the First Circuit and any other circuits that decide to follow it

\section{Deloitte}

In 2010, the influence D.C. Circuit Court of Appeals ruled on a wide variety of issues related to the tax accrual Work-papers. The Court rejected the Textron (2009) and El Paso (1984) decisions. This decision is very favorable to both corporations and the accounting profession. The case involves Dow Chemical Company's 2005 refund suit challenging adjustments made by the Internal Revenue Service to two partnership returns for partnerships in which Dow is the principle owner. During the discovery phase, the Service sought the workpapers of Dow's independent accountants, Deloitte \& Touche, LLP., documents prepared by Dow employees, an accountant and in-house attorney, and a 2005 tax opinion prepared by Dow's outside counsel. All three were in possession of Deloitte. Deloitte complied except as to the Dow documents and a draft memorandum prepared by Deloitte about the possibility of litigation and the necessity of accounting for a possible IRS audit. It included a summary of discussions that took place at a meeting among Dow employees, Dow's outside counsel and Deloitte employees about the possibility of litigation over the partnership and the need to account for such in the financial statements. These described in Dow's privilege $\log$ and it asserted work product protection. The government sought the 
assistance of the court to enforce its summons (United States v. Deloitte, 2010).

The Dow documents and the meeting were necessary so that Deloitte could "review the adequacy of Dow's contingency reserves" for the items that were in question. Deloitte insisted on this "in order to provide Dow with an unqualified audit opinion for its public financial statements." (U.S. v. Deloitte, 2010, p. ) This would be the norm under SOX, FIN 48 and to prepare the Schedule UTP.

As to the two Dow documents, the government conceded that the Dow documents were protected as work product, but alleged that Dow waived its privilege by giving them to Deloitte. In regards to the Deloitte document, the government asserted that if the court found they were covered by work product protection, it was waived when Dow orally disclosed to Deloitte employees the information included in it. (U.S. v. Deloitte, 2010).

The Court explained, "[ $t$ o the best of our knowledge, no circuit has addressed whether disclosing work product to an independent auditor constitutes a waiver." (U.S. v. Deloitte, 2010 p. ) A waiver generally is found when work product is voluntarily disclosed to an adversary or a conduit to an adversary. The majority of courts, not at the circuit level, that have looked at this issue have not found a waiver(U.S. v. Deloitte, 2010) .

The government alleged that disputes sometimes arise between independent auditors and their clients. The court indicated that the real question is "whether Deloitte could be Dow's adversary in the sort of litigation the Dow documents address" not just if they could ever be an adversary (U. S. v. Deloitte, 2010, p. 140). The documents were prepared concerning possible litigation with the IRS, not Deloitte, so they are not a potential adversary. Likewise they are not a conduit to Dow's adversaries since Dow had a "reasonable expectation of confidentiality because Deloitte, as an independent auditor, has an obligation to refrain from disclosure of confidential client information" (U. S. v. Deloitte, 2010, 
p. 141). These obligations are both contractual and ethical under the Code of Professional Conduct (AICPA). The Court also disagreed with the government on the applicability of the Arthur Young (1984) case holding that it was not applicable because what was sought was not the independent auditor's interpretations of the financial statements but the opinion work product of its attorneys in anticipation of potential litigation with the government(U.S. v. Deloitte, 2010).

The Court's ruling of the waiver did not resolve the issue of whether the Deloitte document was covered by work product privilege. The government contended that Dow cannot claim work product protection for the Deloitte Memorandum because it was prepared by Deloitte. It asked the Court to take a narrow view of FRCP§26(b)(3). It contended that the Rule only protects "documents and tangible things that are prepared ... by or for another party or its representative." (FRCP§26(b) (3)(A)). They argued that Deloitte is not Dow's representative.

The Court took an expansive view of the work product protection. It indicated that the privilege is beyond just the Rule and Hickman (1941), as it provides work-product protection for intangible work product independent of Rule 26(b)(3). The court focused on content not who produced the documents. This distinguishes the case from Textron (2009). As a result, "Deloitte's preparation of the document does not exclude the possibility that it contains Dow's work product” (U. S v. Deloitte, 2010, p. 130).

The next critical issue was whether the document was prepared in anticipation of litigation. The Court adopted the majority "because of rule." As discussed earlier, application of this test can be problematic. The court evaluated the documents at issue by examining their contents.. The Court recognized that documents can serve a "Dual Purpose" or in some cases multiple purposes. That fact that the document may serve more than one purpose; for example reporting for SOX, FIN48 or Schedule UTP, does not mean it does not contain protected work product. 
The inquiry is on the content of the documents to determine if it is prepared in anticipation of litigation.

The Deloitte case represents a major victory for the protection of accountants' work-papers. It is of even greater significance by the fact that the D.C. Circuit precedent on evidentiary issues is controlling in the Tax Court. (Tax Court Rule 143(a))

\section{Conchusion}

In an attempt to attenuate a perceived loss of confidence in the voracity of financial statements issued by public companies, a number of new standards and regulations have been enacted by various regulatory agencies and Congress. The most pivotal examples being the SarbanesOxley Act of 2002 (SOX), Financial Accounting Standards Board, Interpretation No. 48, Accounting for Uncertainty in Income Taxes (FIN 48) and the Internal Revenue Service's Schedule UTP. As a result of the new requirements compelling some corporations to disclose information on their uncertain tax positions, and the IRS attempts to demand disclosure of the accounting workpapers, both internal and external, there is a potential chilling effect on previous legal protections afford to those workpapers. Therefore, the interpretations of limits and overall application of these new requirements is of great consequence.

Two Federal District Court cases, Textron (2009) and Deloitte (2010) have highlighted the need for the Supreme Court take up hearing on a related issue case to clarify the rules nationwide. In, Textron (2009) the Court took a position favorable to the IRS severely limiting the work product protections for workpapers and adopted a rule akin to a rebuttable presumption favoring disclosure to the IRS. The Deloitte (2010) Court, however, took a step back and rejected the Textron (2009) holding taking a more expansive view of work product protections. Deloitte (2010), has provided a significant roadblock between the Service and accountants' tax accrual work-papers, including those released to inde- 
pendent auditors and attorneys prepared for non-tax purposes. Until however, the Supreme Court sees fit to take on this issue interpretations will remain in flux as different courts could have divergent interpretations of the rules.

\section{WORKS Cited}

1.AICPA Code of Professional Conduct

2.Announcement 2002-63, 2002-2 C.B. 72

3.Announcement 2010-76, 2010-41 I.R.B. 432.

4.Federal Rules of Civil Procedure

5.Financial Accounting Standards Board, Interpretation No. 48, Accounting for Uncertainty in Income Taxes (June 2006), this is now codified in FASB ASC Topic 740-10. (Fin. Accounting Standards Bd. 2010), cited herein as Fin 48.

6.Hickman v. Taylor, 329 U.S. 495 (1947).

7.Hunt v. Blackburn, 128 U.S. 464 (1888).

8.Internal Revenue Code of 1986 as amended cited herein as IRC.

9.McCarthy, Ryan, United States v Deloitte: The Proper Judicial Approach to Work Product in Light of Broadening Regulatory Requirements Including Schedule UTP, Tax Lawyer, Vol. 65 No. 1, p. 153, (2011).

10.Delaney, Migdail \& Young, Chartered v. IRS, 826 F.2d 124 (D.C.Cir.1987).

11.Sarbanes-Oxley Act of 2002, (P. L. 107-204, 116 Stat. 745, enacted July $30,2002)$, cited herein as SOX.

12.Schedule UTP, Internal Revenue Service, Reg. § 1.6012-2 (a)(4) and (5), see also Announcement 2010-9, 2010-1 C.B. 408; Announcement 2010-17, 2010-1 C.B. 515; Announcement 2010-30, 2010-1 C.B. 668; Announcement 2010-75, 2010-41 I.R.B. 428; adopted 2010.

13.Treasury Regulation $§ 301.6111-3$ (2013). 
14.United States v. Adlman, 134 F.3d 1194, 1196 (CA-2, 1998).

15.United States v. Arthur Young \& Co., 465 U.S. 805, 816 (1984).

16.United States v. Davis, 636 F.2d 1028 (5th Cir. 1981).

17.U.S. v. Frederick, 182 F.3d 496, 500 (CA-7, 1999).

18.U.S. v. Deloitte \& Touche, USA LLP, 623 F. Supp. 2 d 39 (D.D.C., 2009), affirmed in part and vacated in part, 610 F.3d 129, (CA-D.C., 2010).

19.United States v. El Paso Co., 682 F.2d 530 (CA-5, 1982), cert. denied, 466 U.S. 944 (1984).

20.United States v. Powell, 379 U.S. 48, (1964).

21.Upjohn Co. v. United States, 449 U.S. 383 (1981).

22.U.S. v. Textron, Inc., 507 F. Supp. $2 d 138$ (D.C.R.I.), 553 F.3d 87 (CA-1, 2009), op. withdrawn and rehearing en banc ordered, 560 F.3d 513 (CA-1, 2009).

23.U.S. v. Textron, Inc., 577 F.3d 21 (CA-1, 2009) (en banc), cert. denied, 130 S. Ct. 3320 (2010).

\section{Citation Information}

Redpath, Ian J., Thomas J. Vogel, and Eric M. Redpath. "The Controversy over Accountants' Workpapers- Are They Protected from Disclosure to the Internal Revenue Service?" BRC fournal of Advances in Business 2, no. 1 (2014): 25-44. http://dx.doi.org/10.15239/ j.brcadvjb.2014.02.01.ja03 